\title{
Higher EdUCATION IN THE PhilipPines AND MALAYSIA: THE LEARNING REGION IN THE AGE OF KNOWLEDGE-BASED SOCIETIES
}

\author{
Lorraine Symaco \\ Centre for Research in International and Comparative Education (CRICE), \\ Faculty of Education, University of Malaya
}

\begin{abstract}
In the context of the developing world, the notion of the knowledge society has elicited a response especially among higher education institutions (HEIs) and the role of this sector in developing human resources that are able to adapt and compete in such a society has led to the recognition of the government. In the case of the Philippines and Malaysia, for the country to be 'knowledge-economy ready', its HEls must embrace and facilitate a technology-based orientation. This paper will look at the role of higher education in both the Philippines and Malaysia in relation to the requirements of the 'knowledge-based' driven economy and how this sector responds and adapts to the challenging call to 'modernise' in order to perform and maximise its contribution to such objectives. Issues relating to this trend are also examined.
\end{abstract}

\section{Introduction}

The idea of the 'knowledge society' is increasingly becoming widespread in the move towards globalisation and internationalisation. The function played by the university is vitally important in moving towards - i.e., creating - the core of what this modern society ought to be. The systematic move towards the knowledge-based society is dependent on the quality of education systems, higher education specifically (Enders, 1999, Tilak, 2002). One of the main functions of the university is to produce a labour force that is receptive to the ever-changing functions in which it is immersed. At the same time the university is presumed to maintain its function to provide, create and disseminate theoretical knowledge needed for the scientific support of modernising changes in these situations. In short, the increasing formation and production of both theoretical and practical knowledge through creative research, technological diffusion and innovation are integral in the knowledge-based society. The ability to create such ideas and knowledge fuels development, and it has been argued that a country's productivity and growth are mirrored now, more than ever, through its human resources rather than its natural resources. The ability to "create new knowledge and ideas and to incorporate them into equipment and people" is what is significant now (David \& Foray, 2002, p.9).

In the context of the developing world, the notion of the knowledge society has elicited a response especially among higher education institutions (HEIs), and the role of this sector in developing human resources that are able to adapt and compete in such a society has led to the recognition by the government, in the case of the Philippines and Malaysia, that for the country to be "knowledge-economy ready," its HEls must embrace and facilitate a technology-based orientation. The rise in promoting courses in the sciences and in engineering, which are deemed to be crucial in that kind of economy, and decreasing the "digital divide" by creating greater access to the Internet among the populace are stressed in both countries' government development plans. Similarly in literature, the university creates a learning region where knowledge repositories and increased knowledge spill-over highlight the contribution of such a region to socio-economic development, and certainly stresses the increasingly important role of the university in attaining a country's economic advancement. The economic agglomeration as defined by the New Economic Geography and New Growth theories in regional convergence reveals the function of universities in this regard through the generation of such learning regions. The function of higher education institutions in responding to the needs of the knowledge economy (through generation of highly skilled human resource) and at the same time producing knowledge repositories that at a basic level advances the creation of the knowledge economy gives the universities a unique creative role in the knowledge society. As the growing trend to modernise and adapt to the needs of increasing globalisation and internationalisation of services may compel developing

1

${ }^{1}$ Correspondence can be directed to: lorraine@symaco.org 
countries to gear towards this call for modernisation, issues such as proper financial allocation, inequity and, problems to access to such services as pertinent to peripheral areas are present. This paper will look at the role of higher education in both the Philippines and Malaysia in relation to the requirements of the 'knowledge-based' driven economy and how this sector responds and adapts to the challenging call to 'modernise' in order to perform and maximise its contribution to such objectives. Issues relating to this trend are also examined. This study involves both documentary (primary and secondary) and empirical research, as well as contextual studies necessary to situate the Philippines and Malaysia accurately in their regional and global setting. Documentary sources include policy-planning sources from the Philippine and Malaysian authorities and local agencies. Empirical research, from interviews in institutions and from central authorities, maintains relevance of the issues mentioned.

\section{Regional Convergence: New Economic Geography and New Growth Theory}

The theory of the New Economic Geography centres on a variant of one fundamental question, namely, the question of what factors have influenced or continue to influence the geographical distribution of economic activities (Schmutzler, 1999). As Schmutzler goes on to clarify, this concept considers economic agglomeration to be unrelated to the natural reserve of an area. The ascendancy of particular areas is in fact dependent on other factors, most often through 'self-reinforcing' activities, including the generally balanced play of dynamics between an industry and its suppliers and customers, and interactions between different markets. The basic underlying directive of the New Economic Geography according to Schmutzler, is that economic agglomeration tends to occur in areas where there are increasing returns to scale, with transport costs playing an important role; locations that are closer to both the market and to suppliers are considered more desirable, other things being equal. This concentration of economic activities tends to attract factors of production, and a condensed production profile in an area leads to a more stable base for workers. In effect, the focus of the labour market in one particular area results in higher consumption of goods, which in turn leads to a rise in profits for producers. The dominance of production in a certain region therefore signifies regional dominance, which in turn attracts firms to relocate there, thus revealing a positive interplay between production and consumption, which results in what is known as 'clustering' in the terminology of economic geography.

However, the importance of locational proximity is countered by the concept of 'relational proximity', which focuses on agglomeration or "communities" of practices and asserts that if the organisational or 'virtual community' (Gertler, 2003) is formidable enough, then the transfer of knowledge across all geographical dimensions is possible. Despite this contention, there is an increasing focus in the 'New Economic Geography' and the relation it bears to higher educational institutions, regional development and the development of knowledge creation and diffusion (Clark, et al., 2000; Krugman, 1998). The production, acquisition and transfer of knowledge are considered crucial in order that industries remain competitive in the era of the global market. This model of the economy's 'internal structure' related to the external takes into account the issue created by "distributed organisations" (Gertler, 2003), and the heavy concentration of organisations in one area, with fewer in another, that is to say, spatial disparities.

The significance of technological change and human capital is on the one hand emphasised by 'New Growth' theories, which veer away from neoclassical models by considering such factors (technological change and human capital) as endogenous to the production function. 'New Growth' theories emphasise the significance of human resource (i.e., manpower) and modernisation as exemplified through technological change in development. Applying this notion to the university's contribution in terms of development can be connected to the concept of knowledgebased economies. The term 'knowledge capitalism', which emerges from the idea of knowledge-based economies, are characterised by: (a) economics of abundance; (b) the annihilation of distance; (c) de-territorialisation of the state; and (d) investment in human capital (Olssen \& Peters, 2005). The further shift from traditional economies to more dynamic relationships between the government, university and industry is vital in order to sustain the needs and demands of the knowledge society (Burton-Jones, 1999; OECD, 1996).

In addition to the basic underlying presumption of higher education's role in developing human capital and new knowledge is shown by the New Growth theory, which also looks at the possibilities of other education-externalities related to economic growth. The increasing importance of science and technology in policies points to the rising agreement on macroeconomics of 'new growth' (Olssen \& Peters, 2005). As explained by Lucas (1988) and Romer (1994), the influence of technological change in economic advancement is significant. The role of the university in generating this technological change and advancement as seen through R \& D (Research and Development) activities and patent generation, among others, is also highlighted through higher education's contribution to development.

Despite the considerable contribution of the knowledge-based society, the problem of access to such 'knowledge' and 'information' is a major point to consider. The implication of sustaining different levels of knowledge transfers means the delivering of differential developmental patterns in different levels of society. Knowledge gaps can therefore block/stultifies growth and advancement in poorer societies. As typified by the 'digital divide', this disparity between core and peripheral societies and countries is seen to worsen due to the 


\section{Higher EdUCATION IN THE PHILIPPINES AND MALAYSIA}

inability of poorer communities to access technological knowledge, skills and information. Growth areas are often characterised by the position of industries relevant to this theme of modernisation that exclude people who are not equipped with the proper training to adapt according to the demands of the market. Jobs are available to individuals who are already in that 'growth area' and those who already have relevant education qualifications. In the perception of neo-exclusions in government policies, the threat of discriminating between groups of people such as the included (those who are 'properly' trained) and excluded (those with less qualifications for 'getting into' the 'growth area') is present. Obviously, in peripheral societies where exclusion from certain aspects of modern development is expected, it is all the more presumed that recognised 'information and technology' together with contemporary 'communication networks' do not counteract this state of segregation (Hayrinen-Alestalo, 2001), and may even intensify it.

As drawn above in rough, empirics on regional convergence offer various theoretical accounts in explaining regional growth and development, and New Growth or Endogenous Growth theorists contribute substantially in this endeavor:

...key factors stressed by endogenous growth theory--increasing returns, human capital and technology-develop unevenly across the space economy and are locally and regionally differentiated. Endogenous growth theory undoubtedly offers some possible explanations of global-local interactions and the dynamics of regional growth, most of which revolve around these key factors (Martin \& Sunley, 1998, p. 220).

Nonetheless, limitations to this theory point to its failure to take into consideration "socio-institutional contexts" of regional development. Moreover, it has failed to regard geography and place as considerably significant in regional convergence (Martin, 1999; Martin \& Sunley, 1998).

\section{The University and the Learning Region}

The creation of knowledge and human capital formation are highlighted by Goldstein et al., (1995) as among the outputs of the university that contribute to socio-economic advancement. The university's function in the creation of knowledge has been its raison d' être since its foundation during the Middle Ages, and even before. This is further highlighted in the university's relationship with 'industry' as the national undertaking embracing all human production that designates the university as the head of the supply chain --in 'industry' as above defined-committed to the provision of knowledge needed by such 'industry' (Goddard, 1997, p.9). Successful regions are said to be characterised by "institutional thickness" (Amin \& Thrift, 1994) that exhibit the sharing of information and expertise among institutions leading to collaborative progress. On the basis of this idea, the university's substantial role in such regions is recognised. Learning regions may be defined as areas where universities play a major function in socio-economic development. These academic institutions, based in the community, serve as knowledge repositories and generators, often indirectly through their graduates and retired professors, and these people's projects and involvement in various institutions and business companies. Of course, there in the immediate scene the university generates jobs by giving people the skills needed in industry. The university as a learning environment imparts skills that allow all kinds of industries in the spectrum of the modern world to remain competitive in their fields. The transfer of existing knowledge and 'know-how' through the professional development of individuals including those who could provide tactical analysis and leadership within the local community is among a university's functions (Goddard, 1997).

Boucher et al. (2003, p. 889) further list the contributions of universities to their locale. The first role of a university as an economic contributor is played by it as an employer, payer of wages and salaries, buyer of products and services from local firms, and attractor of students who spend money in the regional economy. 'Conscription' of students has been 'internationalised' by universities who try to attract foreign students with the promise of providing quality education. The second role, and to which this article centres on, includes using the knowledge generated in and belonging to the university to obtain patents, set up spin- off companies, or market the knowledge as 'technology transfer' to existing companies, to individuals, or to countries. The rise in modernisation coupled by the trend of 'knowledge economies' highlights the significance of regional convergence in development as can be provided for by universities. The social development function role of the university, on the other hand, which is of course fundamental, is its role as an educator and its 'custodianship' of students. It imparts to them not only the aptitudes required by industries in the region, but possibly the qualifications that would enable them to be accepted by national institutions of learning that would give them further competence for intellectual, artistic, or technological achievements that would benefit the whole nation or perhaps all of mankind. This role of the university, as will be discussed further, also includes its participation as an institutional 'player' with other 'players' in the region (e.g., research firms and industries) in networks of learning, innovation and governance. In a broader local sense, universities and others HEls have a very significant 'multiplier effect' in terms of a wide range of 
employment from technicians through secretaries to cleaners and food suppliers. This is akin to the clustering of suppliers of components for a large manufacturing facility.

The common propositions of the learning region are further highlighted by Mackinnon et al. (2002). Since learning regions through the universities in them are believed to be repositories of knowledge for tacit, specialised skills which drive a region to substantial advantages, this onus on the university is unavoidable. It requires it to infuse in its development an "evolutionary ethic" to enable it to perform its role as "centre of knowledge and of progress in learning" in its region, since its relationship with industries in the region must be a symbiotic one-it provides industries with competent human resources, and industries come to that region, with its offering of jobs and possibly national recognition as a good place for branches, research, or total resettlement. There is a tacit understanding that the knowledge and intellectual resources of the region will keep pace with the wider world in respect of progress in science, technology, and human knowledge in general, for present-day reliance on computer resources are still no substitute for direct human contacts with people in the knowledge and technology fields.

Mackinnon et al. (2002) further claims that geographical proximity to the source of knowledge and the importance of transmitting tacit knowledge through interpersonal relations tend to bring together groups of specialists and people in regional industries, this 'clustering' exemplifies in application the theory of New Economic Geography in relation to higher education institutions. Through their employment they have specialised knowledge, expertise, or interests in particular areas of knowledge and technology, bringing them together in the learning region. This in turn provides facilities and an atmosphere where embedded learning and the pursuit of special scientific knowledge, innovation, and experimentation are in the culture and accessible. Social relations are fostered between the said industries and academe. As a natural consequence this, in turn, indirectly brings about socioeconomic development in the community through the provision of jobs to the populace traceable to the coordination between industry and academe to respect and attend to, within their respective roles and responsibilities, the needs of the other. Obviously, a collective learning process is advanced through the situation described. This learning process has been defined as "a cumulative learning process that takes place over time among a community of firms in a locality" (Mackinnon et al. 2002, p.301).

This definition well describes the situation above drawn in rough, provided that 'firms' is understood to include the 'centres of learning' in the locality-the university and other relevant bodies. Collective learning in the process becomes a public good such that the knowledge generated is not limited to the direct producers who benefit from the knowledge and the insights gained, the 'feedback' from students and academic researchers, the inspiration and motivation attendant to success. The knowledge transmitted directly or indirectly by the university disseminated to the public formally and informally through publication, teaching, networking and other forms of communication. Advancement is thus seen when less developed regions divide themselves into learning regions.

\section{Commercialisation of University Findings with Technology Relevance}

The link between higher education and instrumentality did not originate in modern times. However, interest in this link has necessarily increased at the turn of the millennium because of rapid revolutionary progress in technology related to university courses in the 'pure sciences' (theoretical mathematics and physics) and 'applied sciences' (engineering, medicine, computer science, among others) as exemplified by the New Growth theories as aforementioned. Nelson and Phelps (1966) suggested long ago in a model that in a progressive economy, education has a positive recompense only if through technology it continuously improves. They suggested that the causal relation between higher education and technological advances and the diffusion of such advances is shown by the fact that investment in human capital, through investment in education, equips workers and managers with skills and knowledge necessary for innovation. External expectations for universities to generate development in the sciences and related fields and for them to obtain income through their own activities have made the universities necessary 'players' and therefore stakeholders in technology transfers, mainly through the take-up of university research results in the production of industrial or commercial facilities of goods or the improvement of such. There is increasing recognition of the university's role in the production of such facilities or goods needed in industry. That is to say, transferring 'university research based' findings to industry (Parker \& Zilberman, 1993; Powers \& McDougall, 2003). Hence in recent times there has arisen the phenomenon of universities that make use of entrepreneurial ventures or projects on the side, sometimes setting up 'spin offs' through university-owned companies and getting involved in patents, manufacture of things patented directly or indirectly, and licensing of patents to companies. In that way, the university goes into venture capitalism. As Powers and McDougall (2003) pointed out, the 'framing -out' of licenses possibly accompanied with a stake equity contribution, have in many cases resulted in considerable positive returns even if only a few firms in the university's portfolio go public through distribution outlets of trade (or 'market') exchanges.

The said university-industry link is characteristic of the learning regions in a country. Marshall (1920) gave three grounds for the geographical preference of industries for localisation, and these are: (1) the aggregate demand for specialised labour; (2) the development of specialised intermediate goods industries, and (3) knowledge spill overs 
among firms in an industry where they are physically proximate to each other. Economic geography plays a major role in the concept: knowledge spill overs which are said to be geographically bounded and often confined within a spatial range to the knowledge source (Audretsch \& Lehmann 2005). Knowledge spill-overs from universities, however, do not result in costless transfers across geographical regions. It is implied that proximity to the knowledge source, in this case the university, plays a significant role in the ease of access to such (Audretsch \& Lehmann, 2005), as well as its application. As a consequence, industries are attracted to localities where an active knowledge-producing university is based, such as is maintained by the learning region premise. Examples of this are the science industry parks that are now found on or near the campuses of many universities. Spill overs of academic research and human resources in terms of highly trained, educated students and professors, and knowledge left non-viable but showing promise for further development or revision, contribute to technological advancement.

The acquisition of patents by universities also serves as a means to safeguard future potential by signaling to the industry the intention of such institutions to venture into further research possibly leading to commercialisation. This in effect may attract more established firms to provide material assistance for managing the development and refinement of the technology. From the perspective of venture capitalists, a company with a particular management expertise may be interested to invest, and thus have greater assurance in obtaining, possibly at a premium price, a license to such patented technology (Powers \& McDougall 2003). In such an arrangement, the university would not only retain the right to develop or refine the knowledge related to the technological innovation, but also investment from the rest of the industry and the commercialisation of the innovation. If its worth to industry and commerce is validated, it would result in job formation, for the demand for skilled workers for start- up companies would of course increase.

The following sections will look at the national contexts of the tertiary sectors of the Philippines and Malaysia in response to the increasing call to 'modernise' in the knowledge society. Similarly, the knowledge environment as parallel to the learning region as defined above as contributed and 'aimed for' by higher education institutions in attaining regional convergence is also discussed. However, issues surrounding toward such moves in both countries are also apparent.

\section{Labour Force and the Knowledge- Based Society in the Philippines and Malaysia}

Malaysia's goal of becoming a developed nation by 2020 is characterised by the existence of the "k-economy", or the knowledge-based economy in its development plans. Parallel to this is the emphasis on science and technology (S\&T) and, research development. The Ninth Malaysian Plan (development plan for years 2006- 2010) by the government underlines this by acknowledging the importance of leverage in these areas in order to attain greater national development. Towards this end, the government intended to increase national expenditure in research and development (R\&D) to 1.5 per cent of GDP by 2010. Additionally, a target of 50 research scientists and engineers (RSEs) per 10,000 labour-force is also envisaged ${ }^{1}$ (EPU 2006). Technology coupled with research and development is considered the crucial focus for achieving the status of a developed nation. As echoed by a university Vice-Chancellor in Malaysia: "Technology will be the fundamental pushing factor for the development of the country." Similarly for the Philippines, the long-term higher education development plan for 2001-2010 also emphasised the need to equip its human resource with the know-how of Information Communication Technology (ICT). This is seen as "paving the way towards regional and global integration and the emergence of a borderless world or global village" (CHED, 2001, p.1). The Philippines has prioritised the mobilisation of knowledge and ICT for development and job creation. Current efforts in promoting the sciences and ICT are among the matters at the forefront of the national agenda in the country. There is a conscious effort to make science and technology consistent with national development goals.

On the one hand, the shift of focus to a knowledge-based economy has influenced Malaysia's priority to steer the demand for higher education in this direction. The desired structural evolution of the Malaysian economy from agricultural to industrial and technological creates a flexible higher education sector attuned to the needs of the modern economy. But this assertion does not go undisputed as exemplified by a university professor. "Malaysia has not said what a developed nation is. If you do not know where you're going, any road will take you."

While acknowledging the manifestations of the knowledge-based economy, the Philippines does not place as much emphasis as Malaysia on gearing its manpower to respond effectively to the challenges posed by the global market, as shown for instance by the sharp contrast in terms of the massive investment made by the Malaysian government in this field. Interestingly, some stakeholders have supported the further strengthening of the emphasis on agriculture in the Philippines, due to the country's vast wealth in relevant natural resources. Central planning in Malaysia has focused heavily on predicted outcomes and requirements, considered necessary for functioning efficiently in the knowledge-based economy, but Malaysia's reliance on this has been criticised. 
I wish we had higher education more in agriculture, you know, higher education more on utilising our natural resources more than graduates in MBAs [Masters in Business Administration] per bank.

(Business executive of a local company in the Philippines)

I'm sure they [Malaysia] made a lot of mistakes, that's characteristic of centrally planned economies; you put resources in areas which don't turn out to be right. They bet on the wrong horse in effect, so there are advantages and disadvantages. If you bet right then ok.

(Professor of a university in the Philippines)

The construction of the Multimedia Super Corridor (MSC) in Malaysia in 1997 was the primary expression of the country's intention to embrace the knowledge-based economy. The practicability of this project, backed by huge investment from the government, a project which has advocated the emergence of technology as a necessary prerequisite for development, has however been open to question.

\section{Multimedia Super Corridor: Development Catalyst?}

The initial setting-up of the Multimedia Super Corridor by the government in 1997 was aimed at making Malaysia the technological hub of the region (Abbott 2004). The government's view was that achieving this technological capacity would pave the way to realising the goals of Vision 2020, that envisions Malaysia to be a developed nation by year 2020. The MSC is one among many mega-projects which symbolise Malaysia's repositioning towards progress. The MSC is composed of two cities, Putrajaya, the electronic administrative centre for federal government, and Cyberjaya, an "intelligent city" (Bunnell, 2002), and the MSC also contains a university that aims to produce graduates who are adept at responding to the needs of the k-economy. The government is also keen to attract multinational ICT companies to invest in locating their home bases in the MSC, and incentive schemes and tax concessions aimed at attracting foreign investors have been set up by the Malaysian government. But over and above these incentives, the MSC is considered by the government as an advanced technological milieu that by its very nature would attract entrepreneurs and investments that will promote techno-scientific knowledge.

This project has not, as above-mentioned, passed without criticism. Some consider it to be excessively costly, with an estimated budget of 20 billion US Dollars (Abbott, 2004), and claim that it is merely a white elephant and one of the extravagant "legacies" of the premiership of the then prime minister Mahathir. A number of multinational companies have taken advantage of tax concessions offered by the government, but none of the major international ICT companies has made MSC its home base in the region (Abbott, 2004).

My perception is very simple. At this rate it will go nowhere. Vision 2020 will be a success, a real estate success. Not in a technological sense. A real estate success because multinational companies come here, all those finished buildings, you see the big ones; they have been standing there empty.

(Professor of a university)

The competition provided by other countries newly entering the manufacturing industry sector has also led Malaysia to concentrate on the technology industry. Inexpensive labour provided by neighbouring countries, and the reaching of a ceiling of the labour-intensive phase (Rasiah, 1995) has obliged Malaysia to reposition itself towards a focus on advanced technology. By the end of 2005, MSC status was granted to 1, 421 companies, most of which focused on software development, data warehousing ad e-commerce. Despite exceeding the first-phase target of 500 MSC companies for the period 1996-2003, the level of content development and innovation products and services has yet to be accomplished (EPU, 2006).

\section{The Digital Divide}

The problem posed by the digital divide, or the segregation between the core and periphery of societies in developing countries as well as in the world as a whole, is an issue which has been created by the advance of ICT. To reduce the effects of this divide, the Malaysian government has introduced programmes to increase the awareness of the use of ICT among rural households (EPU 2006), and similarly, in the Philippines, the introduction of ICT in schools in rural areas has been advocated (NEDA 2006), though no rigorous planning has taken place. In Malaysia, 
the requirement to bridge the 'digital divide' among the country's communities and the need to augment the accessibility to ICT services and structures was acknowledged through the creation of the Universal Service Provision (USP) fund by industry alongside government funding. This joint effort by the government and industry saw an increase in penetration rates from 2000 to 2005 in terms of basic ICT services such as personal computer (PC) installation, (from 9.4 per cent to 21.8 per cent) and Internet dial-up service subscriptions (from 7.1 per cent to 13.9 per cent). This refers to the penetration rate per 100 population. The penetration rate for this matter would refer to the number of active basic ICT service (personal computer use, internet connection) within a specific population (EPU, 2006). Malaysia's broadband penetration reached 31 per cent of households in 2009 and the government aims to raise this to 75 per cent by 2015 (EPU, 2010). The government also promotes a greater awareness of ICT usage in rural communities through ensuring empowerment programmes and the use of the national language Bahasa Melayu and other local languages in line with ICT and e-services updating promotions. The initiative to push ICT skills during the Eighth Malaysia Plan period (2001-2005) resulted in the emergence of more than 31,000 ICT graduates during that phase. These were computer systems designers and analysts, computer programmers and computer support technicians (EPU 2006). Notwithstanding the efforts by the government to promote ICT, the MSC Impact Survey 2005 showed a shortage of the skills needed by the industry and a skills mismatch in the market. This is confirmed thus by a stakeholder from the industry:

I think one of the reasons also is we do not have the right graduates ... and when we produce IT graduates, they're more [of] the lower end of IT graduates, not in terms of capability, but in terms of the subjects they study. That is I think also one of the complaints I hear.

(Business executive in Malaysia)

Beyond the common notion that this exemplifies, namely the impression lack of access to everyday use of the Internet, the thinking of scientists and academicians about the digital divide goes further, extending to access sources such as electronic journals, databases and other resources which are essential to advance research. This lack of access among scientists in developing countries does further harm serves as an obstacle to agricultural, social and economic development, which can be facilitated by knowledge accessible via ICT media (Cullen, 2001). But despite the effort of both governments to connect their citizens with the global age, the problem of supplying enough qualified manpower to deliver the new knowledge, the lack of resources in more remote areas and the misallocation of budget funds are enduring problems. The market's power to dictate its needs in the higher education sector can sometimes also lead a country to switch its priorities to favour professions that are seen as more viable in the international community.

The role of ICT in development is also acknowledged by the Philippine government. Hence, measures to implement training in HEls for programmes in ICT are envisioned by the Philippine government as part of its strategy for better economic performance. Addressing the need to improve the ICT services of the country, the government plans to create more competitive incentive packages for investors, and to improve its ICT human resource. It is, however, not clear how the government would specifically address the former proposal as figures and targets are not given. To achieve the latter objective, it is foreseen that: (a) basic courses, such as science and mathematics, should be improved at all levels of schooling; and (b) tertiary institutions should be encouraged to offer a curriculum with ICT specialisations. To further realise the ICT capability of the country, the Commission on Information and Communications Technology (CICT) was created in 2004. Its main duty is the streamlining of ICT services and programmes (EO 269, 2004). The CICT also envisions building the Philippines Cyberservices Corridor (PCC), aiming to model it on Malaysia's MSC. The country also endeavours, as recognised by the government in the medium-term plan, to provide knowledge and software developments that will push it towards the position as the e-services hub of Asia. The PCC is part of the five 'super regions' identified by the government in its push towards the country's development. The five regions include: northern Luzon for agribusiness capacity, Luzon urban gateway for industry and service centre, central Philippines for tourism, Mindanao for agribusiness, and the cyber corridor for ICT (EO 561, 2006). The interface between the CICT, the Commission on Higher Education and the industry is mainly there to make the existing curricula more relevant to the needs of the ICT industry sector. Additionally, it addresses the skills mismatch, a problem widely recognised in the field. The government also emphasises the reverse of a 'brain drain' through improving employment in the ICT sector, which generated 278,769 additional jobs in the second quarter of 2006 (NEDA, 2007). The Philippines focuses on customer contact centres (call centres), medical transcription, and animation amongst its ICT services. Despite the contention by the government that the provision of jobs within the ICT sector leads to a reversal in the 'brain drain', it does not take into consideration the downward vertical mobility of some professionals who are absorbed by this industry due to the inability of the government to provide the market with alternative high- level job orientations in some, if not most, fields of specialisation. 


\section{Research and Development and Faculty Consultancy}

The contribution of faculty research and consultancy to industry and government is one of the many outputs of higher education. In both the Philippines and Malaysia there is widespread recognition of the role in development played by the expert advice given to the community by members of the university, and consultancy is also said to benefit universities themselves as well as the individuals concerned and their contractors. As well as its importance for professional development, consultancy also serves as a considerable draw to attract and retain qualified faculty members, who can easily earn larger salaries outside the university work (Teague, 1982). The knowledge transfer produced by university faculty members' research work also plays a role in the regional, local and national development of the country. Faculty members' participation goes beyond the lecture room, as faculty resources also enable universities to be contracted, among other roles, to assist in developing national governmental programmes, training government officers and public administration and governance staff, and supporting regional and local activities through outreach programmes, medical missions and the like. The importance of strengthening the interface between the three sectors of university, business and government is also acknowledged.

The government usually taps the faculty members of the universities. In a developing country, there is really a limited number of people with the knowledge and skills that the government requires of in order to assist and define its plans, so they draw from the university often.

(President of a university in the Philippines)

We are getting more and more invitations, not just to do consultancy works but to work with the government agencies on research and all that to provide policy input. The government is also encouraging the private sector to also work within the universities on research on science and technology so I think there is more collaboration between universities and private sectors too.

(Professor of a university in Malaysia)

But despite the policy undertaking to promote and take advantage of faculty expertise in Malaysia, among some members of academia in public higher education institutions there is still discontent regarding the strict and rigid government control over all aspects of higher education, including curriculum development, faculty hiring and other activities and concerns.

The principle now is that we get allocation from the government. So once we get the allocation from the government, we have to follow government procedure in everything. I think the reason why we can't move that fast upward is because of the constraint level.

(Vice Chancellor of university in Malaysia)

The Philippines, on the other hand, illustrates some of the immense responsibilities granted to specific higher education institutions to act as an 'extension' of government services to the community. Despite the obvious contribution to the community, this wide-ranging role is still seen by many academicians as an impediment to other functions of the university including other research activities and more diverse output. The maximisation of knowledge transfer in these extension services has been deemed ineffective due to the lack of 'multiplier' effects observed to date.

The relationship between the university and industry is fundamental for the promotion of knowledge in industry, since the focus on technological innovation, among others, demands a link between the two sectors through discussions involving experts from business and industry and from higher education. The role that faculty members have played in the development of techno-scientific know-how in both countries may not be as significant as in developed countries (Mansfield and Lee 1996), but in recent years this topic has been constantly on the agenda in the development of the programmes of both countries. The research centres devoted to scientific advancement in leading universities in Malaysia and the Philippines also acquire support from the private sector, and professorial chairs are often financed by sectors of industry, showing their interest in further collaboration in and involving universities in their fields of work.

But in spite of the important public service provided by faculty consultancy, some argue that such an 'extended role' might in turn result in "neglect of students and other university activities, abuse academic freedom, conflicts of interest and illegitimate use of institutional resources" (Boyer \& Lewis, 1984, p.637). Nevertheless, Boyer and Lewis (1984) propose that in the face of these criticisms leveled against faculty consultancy, a reasonable assessment of it should involve analysis of trade-offs between the costs and benefits of such practice. Definitive directives to 
educational institutions may be tolerated and followed as long as such directives are not too restrictive (Boyer \& Lewis, 1984).

\section{Knowledge Environment}

The creation of a 'knowledge environment' by the higher education sector in the Philippines and Malaysia, involves universities serving as knowledge repositories for the community by, among other roles, engaging in collaborative ventures with industry to develop and discover new information, and providing access to knowledge through resources such as faculty members, academic libraries and research institutions. This wider knowledge environment implies the use, transfer and creation of ideas as a two-way process involving the university and its milieu (Rowley, 2000). The Philippines and Malaysia have both recognised the significant contribution of their universities in producing and disseminating knowledge which is crucial for the progress of the country. The university is supposed to provide new ideas and perceptions and a social awareness which are constructive for their interface with industry and the government.

The existence of a knowledge environment, made tangible through the presence of a university, is essential for the development of any autonomous region. As previously mentioned, the establishment of a university in the Multimedia Super Corridor in Malaysia is designed to build around it the technological support necessary to disseminate techno-scientific information and other vital knowledge and attitudes. This highlights the important role of the university in gearing itself to the demands of the global market. The MSC is not exclusive to industry's ICT firms; it is also greatly relevant to the university, which plays an important role in the facilitation of knowledge transfer and the training of manpower able to respond to the demands of a modern community. Additionally, under the Ninth Malaysia Plan, emphasis has been given to linking industry and government with the universities through the 'Technopreneur Development Programme' that aims to increase the development of R\&D. Assistance, and links between the groups, goes beyond matching funds; rather there should also be provision of a range of mentoring and technology risk assessment. An increase in the commercialisation of R\&D results and in the number of spin-off companies is also expected. The intensification of the biotechnology industry was given priority by the government through the launching of the National Biotechnology Policy in 2005, which aims to improve the rate of R\&D commercialisation, increase access to funding, increase the number of skilled workers in R\&D, and attract foreign partners in line with the country's vision. Malaysia is said to focus on its areas of competitive advantage such as "its rich biodiversity, leveraging on its multi-ethnic traditional and complementary medicine, and becoming a world leader in resource-based industries such as biofuel and biodiesel" (EPU, 2006, p.27). The presence of the Petronas oil and gas company in Malaysia also plays to the country's aims. The company interestingly, owns a private university, which trains individuals in engineering and technology courses. Specialisations in gas and petrochemical engineering, and petroleum engineering, are available through the courses offered by the university. The university receives financial support from Petronas, and this places Malaysia in relative advantage in terms of training and employment in these technological areas compared to the Philippines and other South East Asian countries.

In the Philippines, the construction of a techno-park in the vicinity of a leading public higher education institution is proof of the desire to connect industry with the academe. However, in comparison with Malaysia, despite the seeming moves of some universities in the Philippines to link-up with industry in terms of research and development, the challenges facing the country in providing greater access and equity in its educational institutions pose a bigger challenge. To improve or provide equal access to higher education, the government encourages computer literacy and has inserted this in the learning experience via "electronic campuses", which are available to people unable to participate in traditional forms of schooling (CHED, 2004). In addition, Open Learning and Distance Learning (including traditional correspondence courses) are among other alternatives on offer in order to promote access and equity in higher education. However, the benefits of ICT in terms of expanding access and equity may not be fully optimised for two reasons, the first being that poor and disadvantaged households may not be able to afford the necessary computing equipment. Secondly, students and their families who are used to traditional forms of teaching may experience what may seem to be undesirable 'switching costs', which may have greater significance for those who come from isolated rural communities.

\section{Closing Remarks: Addressing Competitiveness}

In the case of both the Philippines and Malaysia, despite the intent of each to cement its universities as part of the modernisation process integral in knowledge societies, issues of access and viability exist. As evident especially in developing countries, the tendency of the higher education sector to transform its institutions into knowledge repositories and adopt a research- based orientation is challenged. For instance, as reflective of Malaysia's stance in creating a learning region through the Multimedia Super Corridor (MSC), despite the intent to strengthen regional progress through attracting international companies to locate in the MSC, while providing such companies with human resources through the setting up of a university in its vicinity, the MSC has fallen short of expectations. The ability of neighbouring territories such as Singapore and Hong Kong to attract similar companies as desired by 
Malaysia makes it difficult for the latter to compete in this matter in the region. Despite the tax incentives given by the Malaysian government to companies wishing to settle in the MSC, companies that locate in the MSC more often than not, are employers of lower skills labour (e.g., mass manufacturing). The preparation however of Malaysia in this regard surpasses that of the Philippines in many ways. In terms of technological readiness and innovation, the Philippines ranks way behind Malaysia in country spending in research and development and availability of the latest technologies (Global Innovation Index, 2007, 2011). "Digital divide" which illustrates the lack of access to technology, among others, is also typical of poorer areas in the countries. More specifically for the Philippines, its 'geography of social exclusion' highlights the failure of socially excluded individuals to access basic social services such as education (Bryne, 1995; Warrington, 2005) much more so with regards to accessing 'modernisations' as brought forth by technological advancements. Pacione (1997, p.172), in general, also underlines the inadequacy of the " market model" of education as "...geographically naïve and therefore socially regressive. It does not and cannot address adequately the difficulties of those people and places disadvantaged by the operation of the market."

Faculty consultations and research which can produce knowledge spill over through the commercialisation of technological findings, among others, is also limited. The proportion of student/teacher ratios in developing countries make it difficult for academics to engage in extensive research as opposed to their counterparts in developed countries. The advanced research culture found in the latter also serves to devalue the level of engagement found in developing country institutions. The recognition however of higher education institutions in developing countries of the need to modernise and adapt its tertiary education sector to the increasing role of globalisation and internationalisation is apparent. For instance, Malaysia, in this regard, focuses on the role of its tertiary sector in attracting international students and trans-national campuses (i.e., foreign branch campuses) to its shores. The active role played by its private tertiary sector in linking with foreign bodies through programme accreditations is also worth noting.

Pierre's (2000) theory of 'new governance' proposes that governments should be more receptive to the needs of their environments and adopt strategies that will benefit society at large. This also points to the requirement to maximise provisions and resources that will bring advances to a society. Educational restructuring in several countries resulted from the pressure of a global competitive market that required the ability of states to respond efficiently and effectively to new demands. In the case of the Philippines and Malaysia, attuning to the needs of contemporary society has become apparent (e.g., focusing on research and development, training manpower in highly technical fields) in the desire to adapt its higher education sector not only to local but also to regional and global contexts. Despite the slow but recognised progress in both countries, the need of improving, modernising, and fine-tuning the role of universities in development has been much highlighted by the accelerated move in advanced countries towards a knowledge-based society, which emphasises the urgency to reorganise the formation of human capital in line with the modern global development, particularly in science, technology and research innovations. The development plans of both countries illustrate the valuable role of the university in creating a nation that will exemplify the characteristics required of developing states in order to attempt to at least catch up with the significant development in the advanced countries. The Philippines' long-term higher education plan establishes the need to create and proliferate knowledge that will prepare its people with "competencies, values and skills vital in a dynamically-changing domestic and international environment" (CHED, 2001, p.25). Similarly, for Malaysia the creation of an environment that will keep workers competitive, dynamic and adaptable is regarded as crucial (EPU 2006). It is assured, at least, that the important function of higher education in both countries in local, regional and national development is recognised by both governments, and considered essential for policy reform reorganisation.

\section{Note}

1 The mid term review of the 9th Malaysia Plan notes that the ratio of RSEs was 17.9 in 2006, additionally an increase in private sector expenditure in R\&D is recorded.

\section{References}

Abbott, J. (2004). Mahathir, Malaysia and the multimedia super corridor: Developmental catalyst, white elephant or cultural landmark? In H.S. Mohd and K.L. Phua (Eds.), Public policy, culture and the impact of globalisation in Malaysia. Selangor: Persatuan Sains Sosial Malaysia, 40-58.

Amin, A. \& Thrift, N. (1994). Globalisation, institutions and regional development in Europe. New York: Oxford University Press.

Audretsch, D. \& Lehmann, E. (2005). Does the knowledge spillover theory of entrepreneurship hold for regions? Research Policy, 34(8), 1191-1202. 


\section{Higher EdUCATION IN THE PHILIPPINES AND MALAYSIA}

Boucher, G., Conway C. \& Van Der Meer, E. (2003). Tiers of engagement by universities in their regions' development. Regional Studies, 37(9), 887-897.

Boyer, C. \& Lewis, D. (1984). Faculty consulting: Responsibility or promiscuity? The Journal of Higher Education, 55(5), 637-659.

Bryne, D. (1995). Deindustrialisation and dispossession: An examination of social division in the industrial city, Sociology, 29(1), 95-115.

Bunnell, T. (2002). Multimedia utopia? A geographical critique of high-tech development in Malaysia's multimedia Super Corridor. Antipode, 34(2), 265-295.

Burton-Jones, A. (1999). Knowledge capitalism: Business, work and learning in the new economy. Oxford: Oxford University Press.

CHED (2004). Paper presented at the International Conference on Higher Education, Manila Philippines, March 2004.

CHED (2001). Long-term higher education development plan. Pasig City: CHED

Clark, G., Feldman, M. \& Gerlter, M. (2000). The Oxford handbook of economic geography. Oxford: Oxford University Press.

Cullen, R. (2001). Addressing the digital divide. Online Information Review, 25(5), 311-320.

David, P. \& Foray, D. (2002). An introduction to the economy of the knowledge society. International Social Science Journal, 54(171), 9-23.

De Weert, J. (1999). Contours of the emergent knowledge society: Theoretical debate and implications for higher education research. Higher Education, 38(1), 49-69.

Enders, J. (1999). Crisis? What crisis? The academic profession in the 'knowledge' society. Higher Education, 38(1), 71-81.

EPU. (2006). Ninth Malaysia plan 2006-2010. Putrajaya: Economic Planning Unit.

EPU. (2008). Mid term review of the ninth Malaysia plan 2006-2010. Putrajaya: Economic Planning Unit

EPU. (2010). Tenth Malaysia plan 2011-2015. Putrajaya: Economic Planning Unit.

Executive Order (EO) (2006). (561). Manila: Malacanang.

Executive Order (EO) (2004). (269). Manila: Malacanang.

Gertler, M. (2003). Tacit knowledge and the economic geography of context, or the undefinable tacitness of being (there). Journal of Economic Geography, 3(1), 75-99.

Global Innovation Index. (2007). Available at http://www.managementtoday.co.uk/news/625441/ [accessed 10 October 2008].

Global innovation $\quad$ index. $\quad$ (2011) Available at http://www.globalinnovationindex.org/gii/GII\%20COMPLETE_PRINTWEB.pdf [accessed 26 January 2011].

Goddard, J. (1997). Universities and regional development: An overview. Background paper to OECD project on the response of higher education to regional needs. University of Newcastle upon Tyne.

Goldstien. H., Maier, G. \& Luger, M. (1995). The university as an instrument for economic and business development. In D.Dill \& B. Sporn (Eds.) Emerging patterns of social demand and university reform: Through a glass darkly. Oxford: Pergamon, 105-139.

Hayrinen-Alestalo, M. (2001). Is knowledge-based society a relevant strategy for civil society? Current Sociology, 49(4), 203-218.

Krugman, P. (1998). What's new about the new economic geography? Oxford Review of Economic Policy, 14(2), 717.

Lucas, R. (1988). On the mechanisms of economic development. Journal of Monetary Economics, 22(1), 3-22.

MacKinnon, D., Cumbers A. \& Chapman, K. (2002). Learning, innovation and regional development: A critical appraisal of recent debates. Progress in Human Geography, 26(2), 293-311.

Mansfield E. \& Lee J.Y. (1996). The modern university: Contributor to industrial innovation and recipient of industrial R\&D support. Research Policy, 25(7), 1047-1058.

Marshall, A. (1920). Principles of economics ( $8^{\text {th }}$ edition). London: Macmillan.

Martin, R. (1999). Critical survey. The new 'geographical turn' in economics: some critical reflections. Cambridge Journal of Economics, 23(1), 65-91.

Martin, R. \& Sunley, P. (1998). Slow convergence? The new endogenous growth theory and regional development, Economic Geography, 74(3), 201-227.

NEDA. (2007). Socioeconomic report 2006. Pasig City: NEDA.

NEDA. (2006). Medium-term Philippine development plan. Pasig City: NEDA.

Nelson, R. \& Phelps, E. (1966). Investment in humans, technological diffusion, and economic growth. American Economics Review, 56(2), 69-75.

OECD. (1996). Knowledge-based economy. Paris: OECD. 


\section{LORRAINE SYMACO}

Olssen, M. \& Peters, M. (2005). Neoliberalism, higher education and the knowledge economy: From the free market to knowledge capitalism. Journal of Education Policy, 20(3), 313-345.

Pacione, M. (1997). The geography of educational disadvantage in Glasgow. Applied Geography, 17(3), $169-192$.

Parker, D. \& Zilberman, D. (1993). University technology transfers: Impacts on local and US economies. Contemporary Economic Policy, 11(2), 87-100.

Pierre, J. (2000). Debating governance. Oxford: Oxford University Press.

Powers, J. \& McDougall, P. (2005). University start-up formation and technology licensing with firms that go public: A resource-based view of academic entrepreneurship. Journal of Business Venturing, 20(3), 291-311.

Rasiah, R. (1995). Labour and industrialization in Malaysia. Journal of Contemporary Asia, 25(1), 73-92.

Romer, P. (1994). The origins of endogamous growth. The Journal of Economic Perspectives, 8(1), 3-22.

Rowely J. (2000). Is higher education ready for knowledge management? The International Journal of Educational Management, 14(7), 325-333.

Schmutzler, A. (1999). The new economic geography. Journal of Economic Surveys, 13(4), 355-379.

Symaco, L.P. (2009). Higher education and development in the Philippines and Malaysia: An analysis of the perceptions of the main stakeholders in government, education and business. Unpublished D.Phil. thesis. University of Oxford.

Teague, G. (1982). Faculty consulting: Do universities have "control"? Research in Higher Education, 17(2), $179-186$.

Tilak, J.B.G. (2002). Knowledge society, education and aid. Compare, 32(3), 297-310.

Warrington, M. (2005). Mirage in the desert? Access to educational opportunities in an area of social exclusion. Antipode, 37(4), 796-816. 